\title{
Effect of Seeding Rates and Nitrogen Levels on the Phenological Characteristics and Some of the Other Productive Characteristics of Barley Varieties under Rainfed Conditions in Southern Jordan
}

\author{
Yahya Rawashdeh \\ Ministry of agriculture, Agriculture Directorate Brigade Fqua, Karak.
}

Received: $28 / 12 / 2014$

\begin{abstract}
This research was Carried out during two seasons 2009/10 and 2010/11 at fields of the National Center for Agricultural Research and Extension, it was belong to Ministry of Agriculture in Karak southern Jordan and to study the response of four varieties of barley are Yermok, Athroh, Rum and Acsad-176 to the effect of four seeding rates of 50, 100,150 and $200 \mathrm{~kg} / \mathrm{ha}$ and five levels of nitrogen $(\mathrm{N})$ fertilizer $0,15,30,45,60 \mathrm{~kg} / \mathrm{ha}$ on plant length, spike length, protein percentage and some phenological characteristics. Results of the study showed that the values of all the studied indicators decreased in the second season due to moisture stress rather than in the first season for the second, and vice versa, according to the performance of the product and the degree of adaptability to drought conditions. Variety showed bilateral rows Yermok a high degree of consistency and stability to the contrary from other varieties hexagonal rows. Athroh cultivar took high values for spike length; although it was bilateral rows and access to full maturity in a shorter period of time (131 and 117 days) in the first and second seasons, respectively. Rum cultivar surpassed other varieties and gives higher values for plant length and took longer time to reach full maturity (144.63 and 127.3 days) in the first and second seasons, respectively. The effect of seeding rate was significantly influence on the phenological characteristics but its effect was not significant in indicators yield, knowing that the best values of these indicators have been achieved in the seeding rate $100 \mathrm{~kg} / \mathrm{ha}$. $\mathrm{N}$ level $45 \mathrm{Kg} /$ ha gave the highest value for the protein percentage.
\end{abstract}

Key words: barley, seeding rates, N levels, phenological, spike length.

\section{INTRODUCTION}

Barley (Hordeum vulgare L.) is an important cereal crop in Jordan, ranking the second position after wheat according to the planted area and production of grain, its importance in turn to use it widely as feed, food and it enters in beer production, while straw is used as a source of roughage for animals particularly in arid and semiarid areas (Turk, 1998). Barley grows under different environmental conditions such as marginal areas where the low fertility soils and the low-level of rainfall $(<250 \mathrm{~mm})$ compare with other cereal crops. Barley constitutes about $60 \%$ from the area dedicated to plant cereals in the marginal areas (Turk, 1998). In Jordan, the local barley production during the period from 2005 to 2009 was 91.139 thousand ton, but the imported amounts were 3.63 million ton (Anonymous, 2011). There are some factors which have negative importance effects on the barley production i.e. Low amounts and bad distribution of rainfall (Oweis and Taimeh, 1996), minimal or no use of fertilizers, the planting of low yield cultivars, and improper cultivation practices Haddad et al. (1997). Seeding rate is one of the important production factors. Higher wheat grain yield with better quality requires appropriate seeding rate for different cultivars. Increase in seeding rate above optimum level may only enhance production cost without any increase in grain yield Rafique et al. (2009). The optimum seeding rates for barley always changes according to variety, location and method of planting. In Jordan, most of the barley planting is done by hand- broadcasting depended on approximations of weight and land areas which are used. So the farmers always increase the amount of seeds to compensate the fails which produce by tillage systems and seeds quality Turk and Tawaha (2002).
Understanding of appropriate $\mathrm{N}(\mathrm{N})$ fertilizers levels for Jordanian environmental conditions is very important because this is very correlative with most production components such as grain weight, straw yield, number of spikes and number of tillers at unit area, spike length, number of grain/spike and both size grain and its protein percentage of barley.

Nitrogen is one of the major required elements for plant growth and it is essential for plant growth and development, and is often a limiting factor for high productivities (Costa Crusciol et al., 2003). It is a main constituent of numerous important compounds which found in effective cells, including amino acid, proteins (enzymes), nucleic acids and chlorophyll, by this reasons $\mathrm{N}$ management became very important for cultural practice for farmers of barley particularly new cultivars such as studied cultivars (i.e. Yermok, Athroh, Rum and Acsad-176). N increased spikelets number in the spike of barley (Saleh, 1981), also Abdul Galil et al. (1997) reported that doubling $\mathrm{N}$ level was accompanied by a significant increase in number of grain in the spikelet at all spikelet positions. Several studies recorded that the $\mathrm{N}$ fertilizer increased yield and grain $\mathrm{N}$ concentrations of barley (Zubriski et al., 1970).

This research was undertaken to determine the best response of the studied cultivars for seeding rates and $\mathrm{N}$ fertilizers levels to produce high yield and good quality of barley components.

\section{MATERIALS AND METHODS}

Research was conducted during two growing seasons 2009/2010 and 2010/2011 at Rabba station (120 $\mathrm{km}$ south Amman, $35^{\circ} 45^{\prime}$ longitude; $31^{\circ} 16^{\prime}$ latitude; $920 \mathrm{~m}$ elevation, this station belong to the National Center for Agricultural Research and Extension. The research 
included eighty treatments, were arranged in a split split plot design with three replications. These treatments were the combination of four barley cultivars (i.e. Yermok, Athroh, Rum and Acsad-176) as main plot, four seeding rates $\left(50,100,150\right.$ and $\left.200 \mathrm{~kg} \mathrm{ha}^{-1}\right)$ as sub plots and the sub sub plots were five $\mathrm{N}$ fertilizer levels $\left(0,15,30,45\right.$ and $\left.60 \mathrm{~kg} \mathrm{~N} \mathrm{ha}^{-1}\right)$ as ammonium sulphate $21 \% \mathrm{~N}$ before planting, so that we cannot add high amount of $\mathrm{N}$ fertilizer in the rain-fed regions as Jordan, also the farmer cannot add fertilizer as two dose, due to technically and applied reasons, we added whole amount of fertilizer at one dose with planting. Plot was $5 \mathrm{~m}$ long and consisted of 5 rows placed $25 \mathrm{~cm}$ apart.

Seed bed was prepared before sowing by plowing the site according to the agricultural practices in the region. Seeds were sown on 26 and 24 November in the first and second season, respectively. Before commencement the field experiment, soil samples from $0-25 \mathrm{~cm}$ of the experimental soil site were taken for chemical and physical analysis, results worthy clear that clay loam soil with organic matter $0.98 \%, \mathrm{CaCo}_{3} 24 \%$, $\mathrm{N} 0.95 \%$, P 19.7 ppm, K 386.9 ppm and pH 8.1). The weeds control was applied by using 2, 4 D herbicide when plants reached the three leaf stage and weeded manually every time if there are need at both seasons.

Phenological indicators were executed by following and dating of arrival plants to the main stages of growth, according to the description prepared by Anderson et al. (1985). The emergence of half a spike from flag leaf sheath for about $50 \%$ of the stems for the plants in the plot was adopted as arrival date to heading stage. As for the full maturity stage has been certified when the grain take its size and shape of natural and increases its hardness so that cannot be divided by fingernail, on this basis number of days each stage is the difference between these stages. The length for both plant and spike was measured by using ruler to measure the lengths of fifteen stems and spikes a major representative of the plants plot, plant height from the surface of the soil and till the end of the spike, and the spike length from its base until the end of the upper and then the average of these lengths were adopted as length for the rest of the plants. Protein percentage in grain was determined by the Lowry method (Lowry et al., 1951).

Data were analyzed by using computerized statistical program GenStat. The least significant difference (LSD) at the 0.05 probability to determine the significance of differences among the means (main effects and interaction).

\section{Climatic information:}

The Climatic information were taken from Rabba station for Meteorological Department during experiment implementation at the period from November to April at each season, its explained at Table (1). We had taken this information, so that we know its effect on the growth and productivity of barley. In the first season, precipitation amounts and temperature degrees were very suitable for plant growth and its productivity, for this reason resulted in obtaining high values for the studied parameters such as grain yield and straw yield. At the first season there was high precipitations and good distribution $(399.7 \mathrm{~mm})$ compare with annual precipitations for this region $(339 \mathrm{~mm})$ and the second season $(208.1 \mathrm{~mm})$, so it consider is extraordinary season. During the last week of February, when the plant was at the end of elongation stage, at this period and at beginning of March there was high amounts of rains and suitable temperatures, this optimum conditions catalyzed the plant to grow speedy and given high amounts of dry matter. The reduction of values for most studied parameters in the second season might attribute to low amounts of precipitation.

Table (1): Monthly temperatures (Maximum, Minimum and Mean) and precipitation amounts during two growing seasons 2009/2010 and 2010/2011.

\begin{tabular}{|c|c|c|c|c|c|c|c|c|}
\hline \multirow{3}{*}{ Month } & \multicolumn{6}{|c|}{ Temperature average $\left({ }^{\circ} \mathrm{C}\right)$} & \multirow{2}{*}{\multicolumn{2}{|c|}{ Precipitation (mm) }} \\
\hline & \multicolumn{2}{|c|}{ Max } & \multicolumn{2}{|c|}{ Min } & \multicolumn{2}{|c|}{ Mean } & & \\
\hline & $1^{\text {st }}$ season & $2^{\text {nd }}$ season & $1^{\text {st }}$ season & $2^{\text {nd }}$ season & $1^{\text {st }}$ season & $2^{\text {nd }}$ season & $1^{\text {st }}$ season & $2^{\text {nd }}$ season \\
\hline Nov & 19.4 & 19.6 & 7.8 & 8.2 & 13.6 & 13.9 & 11.7 & 0 \\
\hline Dec & 16.6 & 17.9 & 6.6 & 7.2 & 11.6 & 12.6 & 67.5 & 23.7 \\
\hline Jan & 16.8 & 13.7 & 6.1 & 4.7 & 11.45 & 9.2 & 76 & 65.3 \\
\hline Feb & 16.8 & 13.9 & 6.5 & 5.7 & 11.65 & 9.8 & 217.6 & 78.3 \\
\hline Mar & 19.7 & 18.2 & 8.6 & 5.7 & 14.15 & 11.95 & 26.9 & 23 \\
\hline Apr & 22.6 & 21.7 & 9 & 9 & 15.8 & 15.35 & 0 & 17.8 \\
\hline Total & & & & & & & 399.7 & 208.1 \\
\hline
\end{tabular}

Meteorological Department /Jordan

\section{RESULTS AND DISCUSSION}

\section{A- Phenological characteristics:}

Phenological known as phenomenology which means study of phenomena and stages of growth experienced by the plant and determine the time of occurrence and the extent of vulnerability to climate change and seasonal that occurs during the life cycle. The results of the research Table (2) that the studied varieties showed significant differences among them in all stages of growth experienced by the plant through the seasons. All barley varieties appeared to be earlier in heading and maturity in the second season compared to the first one. These results indicated that barley varieties 
escaped from moisture stress by accelerating the phonological traits. The low level of soil moisture resulting from lack of rain and low quantities in the second season, this means that the species responded to the impact of the prevailing circumstances, trimming cycle of their lives than if these conditions are right, these results agreed with the findings of the (Ceccarelli, 1996) he stated that early in the expulsion of the ears is the means necessary to escape from the influence of environmental stresses surrounding the plant and also (Jana et al., 1990) pointed out that early spike and maturity are indicators on the ability of species to tolerate drought. Athroh cultivar surpassed all other varieties in the early of heading and maturity both seasons. While Rum cultivar was the latest in heading and maturity, the difference between these two varieties was 11.68 days in the heading stage and 11.17 days in maturity.

As given in Table (2) significant difference were recorded between barley varieties for days to maturity. Barley Athroh reached to maturity in the second season earlier than the first one.Acsad-176 was the latest one among the studied varieties during the two seasons. The difference in mean performance of barley variety from one to another might be due to moisture stress, especially in the second season. This response certainly leads to the achievement of the minimum yield and grain yield vital even though rainfall amounts reached their lowest point.

Table (2): Effect of cultivars, seeding rates and $\mathrm{N}$ fertilizer levels on phenololgical characteristics of barley grown under rain fed conditions in 2009/2010 and 2010/1011 seasons.

\begin{tabular}{|c|c|c|c|c|}
\hline \multirow{2}{*}{ Treatment } & \multicolumn{2}{|c|}{ N. days to heading stage } & \multicolumn{2}{|c|}{ N. days to maturity stage } \\
\hline & $1^{\text {st }}$ season & $2^{\text {nd }}$ season & $1^{\text {st }}$ season & $2^{\text {nd }}$ season \\
\hline \multicolumn{5}{|l|}{ Cultivar (C) } \\
\hline Yermok & 98.73 & 92.88 & 137.22 & 121.85 \\
\hline $\begin{array}{l}\text { Athroh } \\
\text { Rum }\end{array}$ & $\begin{array}{c}91.68 \\
104.13\end{array}$ & $\begin{array}{l}87.90 \\
98.80\end{array}$ & $\begin{array}{l}131.35 \\
144.63\end{array}$ & $\begin{array}{l}117.07 \\
127.03\end{array}$ \\
\hline Acsad-176 & 101.73 & 96.67 & 141.88 & 125.07 \\
\hline $\begin{array}{l}\text { Seeding rate } \\
50 \\
100 \\
150 \\
200\end{array}$ & $\begin{array}{c}100.59 \\
99.77 \\
98.48 \\
98.24\end{array}$ & $\begin{array}{l}94.53 \\
93.93 \\
93.57 \\
93.32\end{array}$ & $\begin{array}{l}139.93 \\
138.83 \\
137.96 \\
137.07\end{array}$ & $\begin{array}{l}123.23 \\
122.91 \\
122.31 \\
121.96\end{array}$ \\
\hline \multicolumn{5}{|c|}{$\mathbf{N}$ levels Kg $\mathbf{N ~ h a}{ }^{-1}(\mathrm{~F})$} \\
\hline $\mathbf{0}$ & 99.67 & 94.58 & 139.15 & 123.38 \\
\hline 15 & 99.42 & 94.30 & 138.73 & 123.02 \\
\hline 30 & 99.13 & 93.83 & 137.90 & 122.55 \\
\hline 45 & 99.07 & 93.45 & 138.42 & 122.22 \\
\hline 60 & 99.07 & 93.03 & 138.03 & 121.83 \\
\hline \multicolumn{5}{|l|}{ LSD (0.05) } \\
\hline $\begin{array}{l}C \\
S \\
F \\
C * S \\
C * F\end{array}$ & $\begin{array}{l}1.03 \\
0.98 \\
\mathrm{NS} \\
2.09 \\
1.19\end{array}$ & $\begin{array}{l}0.12 \\
0.14 \\
0.13 \\
\text { NS } \\
\text { NS }\end{array}$ & $\begin{array}{c}0.71 \\
0.45 \\
0.4 \\
1.07 \\
1.02\end{array}$ & $\begin{array}{l}0.21 \\
0.15 \\
0.13 \\
\mathrm{NS} \\
\mathrm{NS}\end{array}$ \\
\hline $\begin{array}{l}S * F \\
C * S * F\end{array}$ & $\begin{array}{l}1.15 \\
2.5\end{array}$ & $\begin{array}{l}0.28 \\
\text { NS }\end{array}$ & $\begin{array}{l}0.84 \\
1.91\end{array}$ & $\begin{array}{l}0.28 \\
\text { NS }\end{array}$ \\
\hline
\end{tabular}

$\mathrm{NS}=$ Non-significant at $\mathrm{P} \leq 0.05$

The effect of seeding rates on the phenological characteristics was clear and significantly during both seasons as in Table (2), where the greatest rate of leaves to decreased the number of days which needed to reach the varieties to heading and maturity. Otherwise this result agreed with what was said (Fukal et al., 1990) and (Dofing and Knight, 1992) in terms of the increased seeding rates accelerate in the arrival of the plant to the most prominent characteristics of phenological such as the number of days required for the formation of the flag leaf and the expulsion of the spike and grain filling and maturity. This also agreed with the results obtained (Ejas Hameed et al., 2003) where it was stated that the rates of few seeds increase the number of days to reach the stage of flowering and grain filling stage and the stage of full maturity. Turk et al. (2003) confirmed the 
high seeding rates stimulated the early evolution of phonological maturity and breadth of flag leaf at about ten days, compared with the least seed. As regards the impact of $\mathrm{N}$ fertilizers on the age of the plant, Table (2) explained that significant differences was registered during both seasons and at all studied growth stages except in the first season for days to heading which was insignificant. It was observed that there is a decrease in the number of days in the two stages of growth (heading and full maturity) has been associated with this decline in increasing the level of $\mathrm{N}$ fertilizer that is, there is an inverse relationship between the age of the plant and the level of $\mathrm{N}$ fertilizer.

As for the impact of interoperability among the factors studied in the phenological characteristics of the plant has emerged as clear in the Table (2) between the level of each of the varieties with seeding rates and levels of $\mathrm{N}$ or seeding rates and $\mathrm{N}$ levels or three factors with each other.

\section{B-Plant height (cm):}

Plant lengths responded to the effect of variation in rainfall between seasons, when the lengths of the plants decreased in the second season due to low precipitation amounts of rain compared to the first season. These data shown us that the cultivars are all responded to the drought conditions and water stress but the Acsad-176 cultivar was more responding to these circumstances. This result coincided with what referred to (Ceccarelli et al., 1987) is that the plant escapes from the drought through the formation of the short stems, that confirm the stem length is the task adjective of the plant in order to adapt and grow in dry areas because the actual impact of the drought, which occurs frequently located primarily on each of stem length and the production of straw.

These values showed that the Rum cultivar morally superior in this capacity on all other cultivars during both seasons, while the averages significantly lower plant height was alternating between Athroh cultivar in the first season and Acsad-176 cultivar in the second season. Acsad-176 gave the largest percentage decrease in plant height; it reached $25 \%$ influenced by the result of severe drought conditions. Stem length is considers of the most important parameter on barley under water stress conditions, and the importance of this trait in breeding operations to improve barley varieties with low plant height under water stress conditions, which makes the process of mechanical harvesting difficult or impossible (Blum, 1988).

The plant length is considered important adjective in barley because of their direct impact on the production of straw and indirectly on the production of grain, this result coincided with the explanation offered by both Blum et al. (1989) and Shaladeh (1984) is that there is a positive and significantly relationship between grain yield and plant height, so in general the plants height a distinct market by its ability to transfer its stock of products of photosynthesis and contribute to fill the grain, therefore the choice of long plants leads to increased production of grain.

The results of the statistical analysis of data experience a lack of significant differences in the average lengths of the plant as a result of the effect of different amounts of seed during seasonal growth as shown in Table (3). It is noted in the first season that the increase in the average length of the plant, although it is not moral but these lengths varied according to the increase in the quantities of seed, while in the second season, we find the values of the average length of this trait has shown a different response from the first season because the height of the plant to decline taking the form of relationship written with any increase in the quantities of seed might be attributed to the low rainfall in the second season, knowing that the outcome of this season, agreed with the findings of the (Turk, 2002) that the lengths of the plants have an inverse relationship with increasing amounts of seed. This result agreed in being not significant with (Hussain et al., 2000).

Regarding the effect of the different rates of $\mathrm{N}$ fertilizer in this trait, the results indicated the statistical analysis of experiment data that there were significant differences in this trait as a result of the impact of this factor during the first growing season only as on the Table (3). These results showed, whether moral in the first season or not moral in the second season that the lengths short belonging to the treatment of the witness, and that the values of plant height increases with any increase in the rates of $\mathrm{N}$ fertilizer, but they come back down as the higher levels. Agreed this result with the findings of each Plenny et al. (1986) and Turk (2002) is that the lengths of plants increase with increasing $\mathrm{N}$ fertilizer.

\section{C- Spike length (cm):}

The results of the statistical analysis of the trial data Table (3) the averages spike length was better in the first season for all studied varieties due to the precipitation of large amounts of rain, compared with the rainfall that occurred in the second growing season, these data show us the importance of the rain and its quantity and distribution is the basis in rain-fed agriculture, which resulted in low levels of rainfall in the second season to drop spike length according to the following percentages: $22.0 \%, 22.6 \%, 16.3 \%, 17.8 \%$ among varieties, Yermok and Athroh and Rum and Acsad-176, respectively. These figures showed that the highest percentage decrease in spike length was returning to the two types of Yermok and Athroh and ratios decrease was attributable at least two types of Rum and Acsad-176. The spike length is important indicators to judge the amount of production as a result of its direct association with the basic elements of the yield of grain and straw. It must be recalled here that the cultivar is of Yermok varieties bilateral rows, while other cultivars hexagonal rows, this thing is one of the basic reasons behind the achievement of significant differences between these varieties at the level of spike length.

About the effect of quantities seed on the spike length, the results of the statistical analysis of the experiment data and significant differences on the spike length as a result of the effect of different amounts of seed during the seasonal growth of the first and second, as shown in Table (3). Seed $50 \mathrm{~kg} /$ ha quantity amounts of seed surpassed morally on other, these data showed 
that there is an inverse relationship between the length of the spike and the amount of seed, when amounts of seed is higher, there is less on the spike length. This thing agree with what he got (Refay, 2009), which amounts of the seed at least, they increase spike length due to the lack of competition between plants on the production factors such as mineral elements in the soil, moisture and light. As well as the Turk (2002) and Turk et al. (2003) said the quantities of seed at least gave the highest values for lengths of spikes. The results of the statistical analysis of the trial data Table (3) the lack of significant differences in the character of the length of the spike as a result of the effect of rates of $\mathrm{N}$ fertilizer during the seasonal growth, can be seen that the averages of this trait increased with any increase in the rate of $\mathrm{N}$ fertilizer that we get the greatest value for the average lengths of these trait at the rate of $45 \mathrm{~kg} \mathrm{~N} / \mathrm{ha}$, then they decreased with $\mathrm{N}$ fertilizer top level. This result comported with the results of many research attributable to each of the Abd El-latif and Salamah (1982) and Turk (2002), which found that an increase in $\mathrm{N}$ generally lead to increasing the length of the spike.

\section{D- Protein percentage:}

The data which presented by Table (3) showed the protein percentage disagreed with other studied parameters, because it increased in the second season, but on the other hand there are decreasing in the values of all parameters in the second season. Might attribute to increasing protein concentration in the grain of little amounts such as grain yield in the second season, this result agree with Varvel and Severson (1987) who reported there were negative relationships between grain yield and grain protein concentration in cereals, but it is nonetheless possible to obtain both yields and high grain protein concentration with appropriate $\mathrm{N}$ fertilizer management. The highest values for protein percentage were $11.09 \%$ and $12.96 \%$; these values were achieved by Acsad-176 barley during the first and second season respectively.

Effect of seeding rate on protein percentage was insignificant Table (3) in both seasons. The result explained there are negative relationship between the values of protein percentage and increasing of seeding rates on first season, but there are contradictory in the second season. These results were supported by the findings of Khaliq et al. (1999) and Hussain et al. (2001).

Protein percentage was significantly responded by $\mathrm{N}$ fertilizer levels during both seasons, so the peak of this percentage $(10.58 \%)$ and $(13.5 \%)$ was conducted by $\mathrm{N}$ fertilizer rate $45 \mathrm{~kg} \mathrm{ha}^{-1}$ at the first and second season respectively, but these values back to reduce with $\mathrm{N}$ fertilizer rate $60 \mathrm{~kg} \mathrm{ha}^{-1}$. These results similar to the results were obtained by Benzian and Lane (1981) and Varvel and Severson (1987) who said grain protein concentration respond to higher rates of $\mathrm{N}$ in a linear relationship.

Table (3): Effect of cultivars, seeding rates and $\mathrm{N}$ fertilizer levels on plant length, spike length and protein $\%$ of barley grown under rain fed conditions in 2009/2010 and 2010/1011 seasons.

\begin{tabular}{|c|c|c|c|c|c|c|}
\hline \multirow{2}{*}{ Treatment } & \multicolumn{2}{|c|}{ Plant length (cm) } & \multicolumn{2}{|c|}{ Spike length $(\mathrm{cm})$} & \multicolumn{2}{|c|}{ Protein \% } \\
\hline & $1^{\text {st }}$ season & $2^{\text {nd }}$ season & $1^{\text {st }}$ season & $2^{\text {nd }}$ season & $1^{\text {st }}$ season & $2^{\text {nd }}$ season \\
\hline \multicolumn{7}{|l|}{ Cultivar (C) } \\
\hline Yermok & 78.0 & 63.1 & 8.48 & 6.62 & 9.39 & 12.45 \\
\hline Athroh & 75.4 & 64.8 & 6.75 & 5.22 & 10 & 12.95 \\
\hline Rum & 91.1 & 77.4 & 4.70 & 3.93 & 10 & 11.94 \\
\hline Acsad-176 & 82.9 & 62.4 & 4.64 & 3.81 & 11.09 & 12.96 \\
\hline Seeding rates $\mathrm{Kg} \mathrm{ha}^{-1}(\mathrm{~S})$ & 78.9 & 69.1 & 7.09 & 5.65 & 10.40 & 12.30 \\
\hline 50 & 80.0 & 69.0 & 6.71 & 5.56 & 10.32 & 12.70 \\
\hline 100 & 80.9 & 65.7 & 6.23 & 5.33 & 9.70 & 13.00 \\
\hline $\begin{array}{l}150 \\
200\end{array}$ & 83.1 & 63.5 & 6.05 & 4.78 & 9.98 & 12.50 \\
\hline \multicolumn{7}{|l|}{$N$ levels Kg $\mathrm{N} \mathrm{ha}^{-1}(\mathrm{~F})$} \\
\hline $\mathbf{0}$ & 80.9 & 66.0 & 6.46 & 5.34 & 9.61 & 11.34 \\
\hline 15 & 84.3 & 66.8 & 6.50 & 5.31 & 9.89 & 12.51 \\
\hline 30 & 82.5 & 67.4 & 6.52 & 5.35 & 10 & 13.4 \\
\hline 45 & 83.8 & 67.5 & 6.63 & 5.25 & 10.58 & 13.56 \\
\hline 60 & 82.9 & 66.4 & 6.48 & 5.41 & 10.43 & 12.55 \\
\hline \multicolumn{7}{|l|}{ LSD (0.05) } \\
\hline $\mathrm{C}$ & 5.21 & 4.27 & 0.32 & NS & NS & NS \\
\hline $\mathbf{S}$ & NS & NS & 0.39 & 0.23 & NS & NS \\
\hline $\mathbf{F}$ & 1.28 & NS & NS & NS & 0.38 & 0.62 \\
\hline $\begin{array}{l}C * S \\
C * F\end{array}$ & NS & NS & NS & 0.78 & NS & NS \\
\hline & NS & NS & 0.49 & NS & NS & NS \\
\hline$S * F$ & NS & NS & NS & NS & NS & NS \\
\hline$C * S * F$ & NS & NS & NS & 1.22 & NS & NS \\
\hline
\end{tabular}

NS $=$ Non-significant at $\mathrm{P} \leq 0.05$ 


\section{REFERENCES}

Abdul Galil, A.A., M. A. Gomaa, H.G.M. Geweifel and Y.E.M. Atta (1997). Response of yield and some grain quality criteria in wheat to $\mathrm{N}$ and phosphorus fertilization. Zagazig J. Agric. Res., 24(4):595-613.

Anderson, P.M., E.A. Oelke and S. R. Simmons (1985). Growth and development guide for spring wheat. University of Minnesota Agricultural Extension Folder AG-FO-2547.

Anonymous (2011). Department of statistics, Agriculture surveys, Food balance sheet, tables of self-sufficiency ratio, 7 august 2011. http://www.dos.gov.jo/agr_a/index.htm

Benzian, B and P. Lane (1981). Interrelationship between $\mathrm{N}$ concentration in grain, grain yield and added fertilizer $\mathrm{N}$ in wheat experiments of southeast England. J. Sci. Food Agric., 32: 35-43.

Blum, A. (1988). Drought resistance. Plant breeding for stress environments. CRC Press, Inc. Boca Raton, Florida, 43-77.

Blum, A., G. Golan, J. Mayer, B. Sinrnene, I. Shipiller and J. Burra (1989). The drought response of landraces of wheat from the North Negev Desert in Israel. Euphytica, 43: 87-96.

Ceccarelli, S. (1996). Adaptation to low/high input cultivation. Euphytica, 92:203-214.

Ceccarelli, S. (1987). Yield potential and drought tolerance of segregating populations of barley in contrasting environments. Euphytica, 36:265273.

Costa Crusciol, C. A, M. Mauad, H. G. Filho and J. C. Correa (2003). Nitrogenand silicon rates fertilization of upland rice. Scientia Agricola, 4:761-765

Dofing, S. M. and C. W. Knight (1992). Heading synchrony and yield components of barley grown in subarctic environments. Crop Sci., 32:13771380.

Ejas, H., A. S. Wajid, A. A. Shed, B, Jehan and M. Tilah (2003). Effect of different planting dates, seed rates and $\mathrm{N}$ levels on wheat. Asian J. Plant Sci., 2(6):467-474.

Fukal, S., C. Searle, H. Baiquni, S. Choenthong and M. Kywe (1990). Growth and grain yield of contrasting barley cultivars under different plant densities. Field Crops Res., 23:239-254.

Gifford, R. M. and L. T. Evans (1981). Photosynthesis, carbon partitioning, and yield. Annu. Rev. Plant Physiol., 32:485-509.

Haddad, N., R. Tutwiler and E. Thomson (1997). Improvement of crop-livestock integration systems in the West Asia and North Africa. ICARDA, Aleppo, Syria.

Hussain, S, A. Sajjad, M. I. Hussain and M. Saleem (2001). Growth and yield response of three wheat varieties to different seeding densities. Int. J. Agric. Biol., 1560-8530.

Jana, S., J. R. Srivastava, A. B. Damania, J. M. Clarce, R. C. Yang and L. Pecetti.(1990). Phenotypic diversity and associations of some drought related characters in durum wheat in the Mediterranean region. In: J.R. Srivastava, and A.B. Damania (eds). Wheat genetic resources: meeting diverse needs. John Wiley and Sons, England.

Khaliq A, M. Iqbal and SMA Basra (1999). Optimization of seeding densities and $\mathrm{N}$ application in wheat cv. Inqalab-91 under Faisalabad conditions. Int. J. Agric. Biol., 1(24):1-3.

Lowry, O.H., N. J. Rosebrough, A. L. Farr and R. J. Randall (1951). Protein measurement with the Folin phenol reagent. J. Biol. Chem., 193(1):265275.

Oweis, T.T and A. Y. Taimeh (1996). Evaluation of a small basin water-harvesting system in the arid region of Jordan. Water Resource. Res., I0:21-34.

Plenny, A., F. V. Widdowson and J. F. Jenkyin (1986). Results from experiments on winter barley measuring the effect of amount and timing of $\mathrm{N}$ fertilisation and some other factors on the yield and $\mathrm{N}$ content on the grain. J. Agric. Sci. (Cambridge), 90:537-549.

Rafique, S.M, M. Rashid, M. M. Akram, J. Ahmad, R. Hussain and A. Razzaq (2009). Optimum seed rate of wheat in available soil moisture under rainfed conditions. J. Agric. Res., 47(2), 143-151.

Refay, Y. A. (2009). Impact of soil moisture stress and seeding rate on yield variability of barely grown in arid environment of Saudi Arabia. AmericanEurasian Journal of Agronomy, 2 (3), 185-191.

Saleh, M.E. (1981). Productivity and floral fertility of wheat plant as affected by some agronomic treatments. Ph. D. Thesis, Fac. of Agric., Zagazig Univ., Egypt.

Shaladeh, G. M. (1984). Inheritance of several morphysiological characters and grain yield of durum wheat crosses. M.Sc. Thesis Faculty of Agricultural, University of Jordan, $162 \mathrm{pp}$.

Turk, M.A. (1998). Effect of $\mathrm{N}$ and phosphorus levels on barley cultivars grain in semi-arid conditions. J. Agron. Crop. Sci., 181:257-262.

Turk, M. A. and A. M. Tawaha (2002). Influence of winter wheat to applied $\mathrm{N}$ with or without ethrel spray under irrigation planted in semi-arid environments. Asian Journal of Plant Sciences, 1(4):464-466.

Turk, M. A., A. R. M. AL-Tawaha, O. Nikus and M. Rifaee (2003). Response of six-row barley to seeding rate with or without ethrel spray in the absence of moisture stress. International journal of agricultural and biology, 5-4. 1560-8530, 416418.

Varvel, G.E and R. K. Severson (1987). Evaluation of cultivar and $\mathrm{N}$ management options for malting barley. Agron. J., 79:459-463.

Zubriski, R. D., E. H. Vasey and E. B. Norum (1970). Influence of $\mathrm{N}$ and potassium fertilizers and dates of seeding on yield and quality of malting barley. Agron. J., 62:216-219. 
تأثير معدلات البذار ومستويات النيتروجين على الخصائص الفينولوجية وبعض الخصائص الإنتاجية الأخرى لأصناف الثعير تحث الظروف المطرية الثين في جنوب الأردن

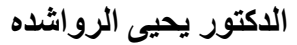 \\ وزارة الزر اعة، مديرية زر اعة لواء فقوع، الكرك
}

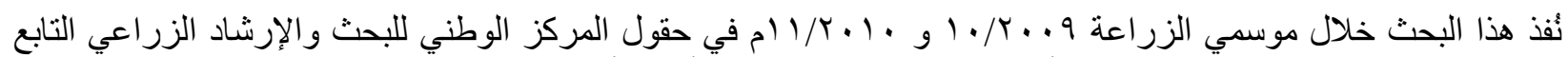

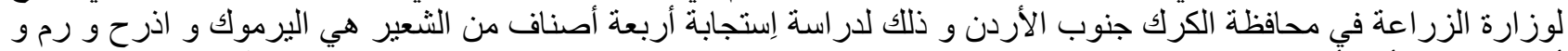

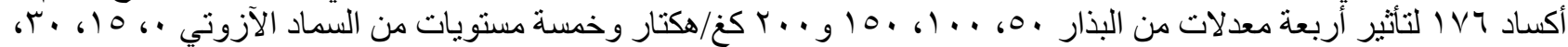

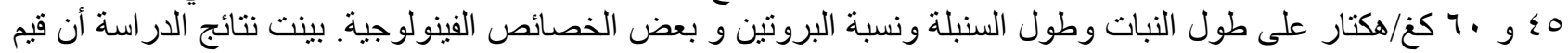

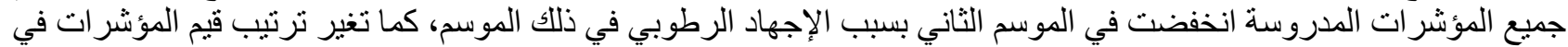

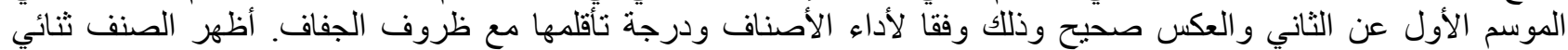

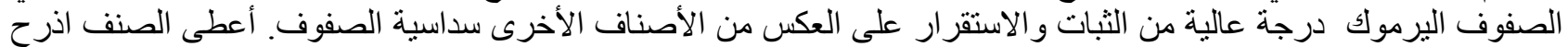

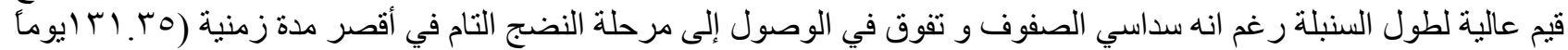

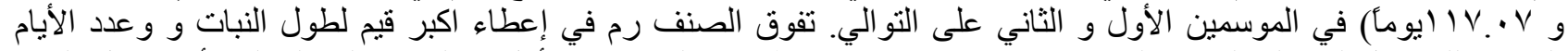

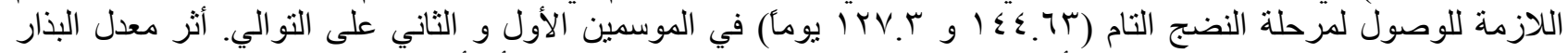

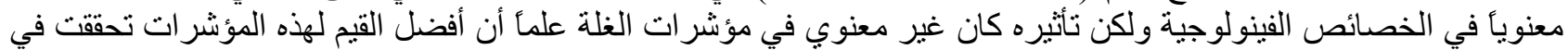

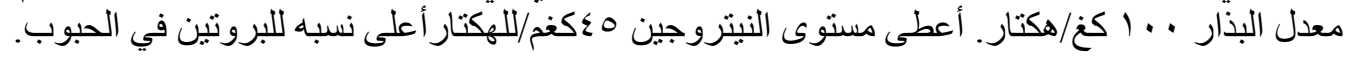
الكلمات المفتاحية: الثعير، معدلات البذار، مستويات النيتروجين، الفينولوجية، طول النبات. 